УДК 65.011.4:657.62

DOI: https://doi.org/10.32782/2520-2200/2019-2-41

Чайка Т.Ю.
кандидат економічних наук,
доцент кафедри економічного аналізу та обліку
Національного технічного університету
"Харківський політехнічний інститут»
Мартинова В.В.
аспірант
Національного технічного університету
"Харківський політехнічний інститут»
Невмирич Д.В.
магістр
Національного технічного університету
"Харківський політехнічний інститут»
Chaika Tatiana
National Technical University
“Kharkiv Polytechnic Institute”
Martinova Viktoriia
National Technical University
“Kharkiv Polytechnic Institute”
Nevmyrych Dmytro
National Technical University
“Kharkiv Polytechnic Institute”

СИСТЕМА КОЕФІЦІЄНТІВ РЕНТАБЕЛЬНОСТІ АКТИВІВ: СУЧАСНІ ТЕНДЕНЦІЇ РОЗРАХУНКУ Й АНАЛІЗУ (НА ПРИКЛАДІ ПІДПРИЄМСТВ СФЕРИ ГОСТИННОСТІ)

\title{
THE SYSTEM OF ASSET PROFITABILITY RATIOS: CURRENT TRENDS IN CALCULATION AND ANALYSIS (ON THE EXAMPLE OF HOSPITALITY INDUSTRY ENTERPRISES)
}

\footnotetext{
У статті проаналізовано наявні методики розрахунку показників рентабельності активів, виявлено наявні неузгодженості в підходах до розрахунку однойменних показників. Емпіричний економіко-статистичний аналіз проводився за даними відкритої фрінансової звітності українських підприємств сорери гостинності. Досліджено аналітичні можливості коефріцієнтів рентабельності активів, які сконструйовані на основі чистого прибутку, прибутку до вирахування відсотків та податків (EBIT), а також прибутку до вирахування відсотків, податків та амортизації основних засобів і нематеріальних активів (EBITDA). Розроблено практичні рекомендації щодо вибору конкретної форми метрики рентабельності активів залежно від цілей аналізу та необхідності врахування структури капіталу, величини фрінансового левериджу, облікової політики, галузевої специфріки забезпеченості основними засобами, методів нарахування амортизаційних відрахувань та життєвого циклу підприємства.

Ключові слова: рентабельність активів (ROA), фрінансова звітність, чистий прибуток (NP), прибуток до вирахування відсотків та податків (EBIT), прибуток до вирахування відсотків, податків та амортизації основних засобів і нематеріальних активів (ЕВITDA), рентабельність необоротних активів (ROFA), рентабельність оборотних активів (RCA), класифікація активів.

В статье проанализированы существующие методики расчета показателей рентабельности активов, выявлены имеющиеся рассогласованности в подходах к расчету одноименных показателей. Эмпирический экономико-статистический анализ проводился по данным открытой фринансовой отчетности украинских предприятий сферы гостеприимства. Исследованы аналитические возможности коэффициентов рентабельности активов, сконструированных на основе чистой прибыли, прибыли до вычета процентов и налогов (EBIT), а также прибыли до вычета процентов,
} 
налогов и амортизации основных средств и нематериальных активов (EBITDA). Разработаны практические рекомендации по выбору конкретной формы метрики рентабельности активов в зависимости от целей анализа и необходимости учета структуры капитала, величины фринансового левериджа, учетной политики, отраслевой специфики обеспеченности основными средствами, методов начисления амортизационных отчислений и жизненного цикла предприятия.

Ключевые слова: рентабельность активов (ROA), фринансовая отчетность, чистая прибыль (NP), прибыль до вычета процентов и налогов (EBIT), прибыль до вычета процентов, налогов и амортизации основных средств и нематериальных активов (EBITDA), рентабельность необоротных активов (ROFA), рентабельность оборотных активов (RCA), классификация активов.

The current differences in methodological approaches of calculating return on assets ratios are a significant obstacle to the success of comparative analytics. Often, indicators that have the same name are calculated in a completely different way. Features forming national financial statements have an impact on the choice of methods for calculating the respective ratios and thus lead to errors when comparing the profitability of assets of business entities of different nationalities. In this regard, it is necessary to clarify the system of indicators of return on assets and improve the methodological approaches to their calculation based on open financial statements. It is necessary to develop a unified approach to the calculation of return on assets ratios, only in this case it is possible to conduct high-quality and relevant comparative analytical work in this area. In this article, an analysis of existing methods of calculating indicators of profitability of assets has been carried out, and there is revealed discrepancies in approaches to calculating indicators of the same name. Analyzed the analytical capabilities of asset profitability ratios, designed on the basis of Net Profit, Earnings before Interest and Taxes (EBIT) and Earnings before Interest, Taxes, Depreciation and Amortization (EBITDA). Practical recommendations have been developed for choosing a specific form of the asset profitability metric depending on the goals of the analysis and the need to take into account the capital structure, the amount of financial leverage, accounting policies, industry-specific security of fixed assets, methods for calculating depreciation charges and the life cycle of an enterprise. The possibilities of forming a set of profitability indicators of assets with their specification for individual groups of assets in accordance with various classification criteria and taking into account the specific objectives of the analysis are considered. Empirical economic and statistical analysis was carried out according to open financial statements of Ukrainian hospitality enterprises.

Key words: Return on Assets (ROA), Financial Statements; Net Profit (NP); Earnings before Interest and Taxes (EBIT), Earnings before Interest, Taxes, Depreciation and Amortization (EBITDA), Return on Fixed Assets (ROFA), Return on Current Assets (RCA), asset classification.

Постановка проблеми. Фінансовий аналіз має виключно великий набір індикаторів ефективності діяльності підприємства, зокрема ефективності використання активів. Удосконалення підходів до вибору конкретної методики розрахунку коефріцієнтів рентабельності активів з урахуванням цілей аналізу $є$ необхідним елементом підвищення якості аналітичної роботи. Чітке обґрунтування вибору методики розрахунку, максимально повний облік факторів впливу сприяють більш точному порівнянню ефективності використання активів на підприємствах з різною специфрікою організації виробничого процесу, різною облікової політикою, різною галузевою та національною приналежністю.

Аналіз останніх досліджень і публікацій. Питання методики формування коефіцієнтів рентабельності активів представлені в роботах таких вчених, як А.А. Нежад, О. Ямралі, M.P. Абоуйафрарі (A.A. Nezhad, O. Yamrali, M.R. Aboujafari) (2014р.) [1], А.C. Дізкіріці, Б. Топал, Х. Ягхі (A.S. Dizkirici, B. Topal, H. Yaghi) (2016 р.) [2], М. Болек (M. Bolek) (2014 р.) [3].

Проблеми економічного сенсу негативних значень рентабельності розглянуті в працях таких науковців, як М. Оберхолцер (M. Oberholzer) (2012 р.) [4], Й.В.Б. Бос, М. Коеттер (J.W.B. Bos, M. Koetter) (2009 p.) [5].

А.В. Озеран (2017р.) [6] присвячує свої роботи вдосконаленню методики розрахунку й аналітичного потенціалу метрики ЕВIT. В роботах Т.В. Ларікової [7], Т.В. Андросової, О.А. Круглової, В.О. Козуб (2014 р.) [8] представлений підхід до розрахунку показників ЕВIT, який ґрунтується на врахуванні особливостей складання фрінансової звітності відповідно до НП(С)БО України.

Проблемам та перспективам реформування законодавства з бухгалтерського обліку та звітності підприємства задля найбільш релевантного подання найважливіших показників діяльності та відповідності міжнародним стандартам присвячені роботи Н.М. Побережної (2017 р.) [9]. Методичний підхід до формування інформації в системі стратегічного управлінського обліку є предметом розгляду в роботах Н.Ю. Єршової (2015 р.) [10].

Класифікаційні ознаки активів підприємства, які можуть бути використані під час формування системи коефіцієнтів рентабель- 
ності активів, досліджені в роботах І.В. Причепи (2012 р.) [11].

Нині національні системи бухгалтерського обліку різних країн зазнають еволюційного процесу трансформації з трендом на уніфрікацію та підвищення ступеня узгодженості облікової політики суб'єктів господарювання. Водночас залишається ще дуже багато проблем у сорері узгодженості методик розрахунку метрик результативності та ефективності діяльності підприємств за даними, отриманими 3 національних форм фрінансової звітності. Очевидно, що наявні розбіжності між методиками розрахунку коефіцієнтів рентабельності активів істотно ускладнюють можливості порівняльної аналітики.

Метою статті $€$ вдосконалення підходів до вибору методики розрахунку коефіцієнтів рентабельності активів залежно від цілей аналізу та специфріки облікової політики підприємства; уточнення аналітичних можливостей окремих коефріцієнтів рентабельності активів; розроблення практичних рекомендацій щодо вибору конкретної методики розрахунку коефіцієнтів рентабельності активів.

Під час дослідження наявних підходів до розрахунку коефіцієнтів рентабельності активів використовувались логіко-аналітичні та системно-структурні методи дослідження.

Інформаційною базою емпіричного економіко-статистичного аналізу стали дані фрінансової звітності українських підприємств готельноресторанного бізнесу за 2012-2017 рр. [12], статистична звітність Державної служби статистики України [13].

Виклад основного матеріалу дослідження. Рентабельність як показник генерації прибутку в розрахунку на одиницю доходів, активів, ресурсів або потоків є однією з найбільш часто використовуваних метрик ефективності. Відповідно до обліку та Національного положення (стандарту) бухгалтерського обліку 1 «Загальні вимоги до фрінансової звітності» активи - це ресурси, контрольовані підприємством у результаті минулих подій, використання яких, як очікується, приведе до отримання економічних вигід у майбутньому [14].

У найбільш загальному вигляді коефріцієнт рентабельності активів (Return on Assets, ROA) може бути виражений таким чином:

$$
R O A=\frac{\text { Profit }}{\text { Assets }},
$$

де Profit - прибуток; Assets - активи.

Слід зазначити, що деякі дослідники ототожнюють рентабельність активів та рентабельність сукупних активів. Так, наприклад, А.А. Нежад, О. Ямралі, М.Р. Абоуйафрарі (2014р.) [1], а також
А.С. Дізкіріці, Б. Топал, Х. Ягхі (2016р.) [2] пропонують розраховувати рентабельність активів (Return on Assets) як частку від ділення чистого прибутку (Net Profit) на сукупні активи (Total Assets), що насправді є формулою рентабельності сукупних активів (Return on Total Assets). Задля недопущення термінологічної плутанини вважаємо за доцільне строго розділяти загальну концептуальну формулу рентабельності активів (1) та їі окремі деталізовані варіації.

Рентабельність сукупних активів (Return on Total Assets, ROTA) може бути виражена таким чином:

$$
\text { ROTA }=\frac{\text { Profit }}{T A},
$$

де TA - сукупні активи (Total Assets).

Дискусійним є питання вибору конкретного виду прибутку в чисельнику формул рентабельності активів. Найбільш поширений підхід передбачає розрахунок рентабельності активів на основі чистого прибутку. Однак існують інші підходи, які необхідно враховувати під час проведення порівняльного аналізу.

Розрахунок рентабельності сукупних активів на основі чистого прибутку $\left(R O T A_{N P}\right)$ здійснюється таким чином:

$$
\operatorname{ROTA}_{N P}=\frac{N P}{T A},
$$

де NP - чистий прибуток (Net Profit, або Net Income).

Розрахунок за фрінансовою звітністю НП(С)БО України може бути здійснений в такий спосіб:

$$
R O T A_{N P}=\frac{\text { код рядка } 2350 \text { (або код рядка 2355) }}{\text { код рядка } 1300}
$$

Особливу увагу слід звернути на випадки негативної рентабельності. Як зазначає, зокрема, М. Оберхолцер (2012р.), рентабельність $€$ метрикою ефективності перетворення наявних ресурсів на результати діяльності підприємства [4]. 3 огляду на цю точку зору слід визнати сумнівність та термінологічну невизначеність поняття "негативна рентабельність». 3 іншого боку, традиція прикладного економіко-статистичного аналізу підтримує поняття негативної рентабельності. Так, наприклад, офіційні статистичні збірники Державної служби статистики України містять дані про негативні значення рентабельності (збитковості) операційної діяльності підприємств та всієї діяльності підприємств [13]. 3 огляду на вищевикладене вважаємо допустимим обчислення рентабельності активів і в разі її негативних значень, проте розуміти в цьому разі іï як коефіцієнт неефективності (inefficiency scores) [5].

У знаменнику формули рентабельності активів може стояти як величина активів на 
кінець розглянутого періоду, так і середнє значення активів за період. В останньому випадку форомула ROTA $A_{N P}$ набуде такого вигляду:

$$
\text { ROTA }_{N P}=\frac{\text { код рядка } 2350 \text { (або код рядка 2355) }}{\frac{1}{2}\left(\begin{array}{c}
\text { код рядка } 1300 \text { на початок року }+ \\
+ \text { код рядка } 1300 \text { на кінець року }
\end{array}\right)} \text {. }
$$

Розрахунок за фрормулою (5) дає більш точні результати, проте часто щодо задоволення цілей аналізу таке підвищення точності не $є$ вирішальним та істотним, тому часто використовується більш проста формула (4).

$R_{\text {RTA }}$ демонструє здатність фрірми генерувати прибуток у розрахунку на одиницю всіх наявних активів без урахування їх структури. Така метрика нечутлива до відмінностей між власними та позиковими коштами.

Розрахунок коефріцієнтів рентабельності активів на основі чистого прибутку є не єдиним наявним в міжнародній практиці фінансового аналізу підходом. Так, вельми популярними метриками прибутку non-GAAP $€$ EBIT (Earnings before Interest and Taxes) та EBITDA (Earnings before Interest, Taxes, depreciation and Amortization). Відповідно, рентабельність сукупних активів може бути розрахована також за такими формулами:

$$
\operatorname{ROTA}_{E B I T}=\frac{E B I T}{T A},
$$

де EBIT - прибуток до вирахування відсотків і податків (Earnings before Interest and Taxes).

$$
\operatorname{ROTA}_{E B I T D A}=\frac{E B I T D A}{T A},
$$

де EBITDA - прибуток до вирахування відсотків, податків і амортизації основних засобів та нематеріальних активів (Earnings before Interest, Taxes, Depreciation and Amortization).

Розрахунок ROTA $A_{E B I T}$ за фрінансовою звітністю НП(С)БО України може бути здійснений таким чином:

$$
\text { ROTA }_{\text {EBIT }}=\frac{\left(\begin{array}{c}
\text { код рядка } 2290 \text { (або код рядка 2295)+ } \\
+ \text { код рядка } 2250
\end{array}\right)}{\text { код рядка } 1300} .
$$

У фрормулі (7) використовуємо варіант аналітичного розрахунку ЕВІT, в якому до фрінансового результату до оподаткування (код рядка 2290 або код рядка 2295) додаються фрінансові витрати, які показують витрати на проценти та інші витрати підприємства, пов'язані із запозиченнями (код рядка 2250). Такий підхід до розрахунку EBIT, зокрема, розміщує у своїй роботі А.В. Озеран (2017 р.) [6].

Розрахунок рентабельності активів за ЕВIT дає змогу проводити порівняння ефективності діяльності підприємств з різною структурою капіталу та не брати до уваги величину фрінансового левериджу. Виникає можливість адекватного порівняння ефективності використання активів підприємств 3 різною часткою позикового капіталу. Крім того, ЕВІТ дає змогу адекватно порівнювати підприємства, які мають різне податкове навантаження (це особливо важливо під час порівняння суб'єктів господарювання різних країн). Як правило, коефріцієнти рентабельності, розраховані на основі метрики прибутку EBIT, використовуються для порівняльного аналізу ефективності підприємств однакової галузевої приналежності.

Щоби мати можливість порівнювати рентабельність активів підприємств різної галузевої приналежності, необхідно мати можливість абстрагуватися від галузевої специфріки забезпеченості основними засобами, а також облікової політики та методів амортизації основних засобів та нематеріальних активів. У цьому разі доцільно використовувати коефіцієнт рентабельності ROTA $A_{\text {EBITDA }}$.

Розрахунок ROTA $A_{\text {EBITDA }}$ за фрінансовою звітністю НП(С)БО України може бути здійснений в такий спосіб:

$$
R O T A_{\text {EBITDA }}=\frac{\left(\begin{array}{c}
\text { код рядка } 2290(\text { або код рядка 2295) }+ \\
+ \text { код рядка } 2250+\text { код рядка 2515 }
\end{array}\right)}{\text { код рядка } 1300} .
$$

На жаль, форми фрінансової звітності НП(С) БО України дають можливість отримати інформацію тільки про амортизацію, яка $є$ елементом операційних витрат. Це знижує точність та достовірність одержуваного в результаті показника. Як зазначає Н.М. Побережна (2017 р.), «практична реалізація затверджених законодавчих змін національного законодавства з бухгалтерського обліку та звітності підприємства призведе, на нашу думку, до розширення сорери застосування форм фрінансової звітності в системі управління функціонуванням та розвитком суб'єктів господарювання» [9]. Однак, як бачимо на прикладі, зокрема, проблем відображення у фрінансовій звітності українських підприємств даних про амортизаційні відрахування, процес удосконалення форм звітності необхідно продовжувати.

Як зазначає Н.Ю. Єршова (2015 р.), під час формування системи стратегічного управлінського обліку суб'єктів господарювання необхідно брати до уваги життєвий цикл організації [10]. Дотримуючись цієї точки зору, вважаємо за необхідне зазначити, що й структура активів, й рівень фрінансового левериджу, й політика нарахування амортизації основних засобів та нематеріальних активів певною мірою залежать від точки на траєкторії життєвого циклу, в якій в конкретний момент часу перебуває підприємство. Очевидно, що під час проведення порівняльного аналізу рентабельності акти- 
вів різних суб'єктів господарювання можуть виникнути ситуації, коли слід абстрагуватися від перерахованих вище факторів. В цьому разі перевагу слід віддавати коефіцієнтами рентабельності активів, які розраховані на основі EBIT i (або) EBITDA.

Варто зазначити, що застосування показників прибутку EBIT і EBITDA в порівняльній аналітиці істотно ускладнене наявністю різних підходів до їх розрахунку. На цю проблему вказує, зокрема, А.В. Озеран (2017 р.) [6]. Деякі українські дослідники, наприклад Т.В. Ларікова (2014р.) [7], спираючись на особливості складання фрінансової звітності згідно з НП(С) БО України, ототожнюють ЕВІТ і фрінансовий результат від операційної діяльності (код рядка 2190 або код рядка 2195). Такої ж точки зору дотримуються Т.В. Андросова, О.А. Круглова, В.О. Козуб (2014 р.), які відзначають, що з огляду на склад компонентів, які фрормують фінансовий результат від операційної діяльності, цей показник відповідає показнику EBIT (Earnings Before Interest and Taxes), який кредитні установи розглядають як основний під час прийняття рішення щодо надання позик [8]. Однак ми вважаємо цей підхід не зовсім виправданим, оскільки він віддаляє вітчизняну методику розрахунку EBIT від її зарубіжних аналогів, чим ускладнює проведення порівняльного аналізу.
У зарубіжній традиції прийнято розрізняти ЕВIT та операційний прибуток, адже, на відміну від EBIT, операційний прибуток не включає доходи й витрати за іншими операціями.

В табл. 1 і на рис. 1 представлена інформація про динаміку коефіцієнтів рентабельності сукупних активів ROTA $A_{N P}, R_{\text {EBIT }}, R O T A_{E B I T D A}$ ПрАТ "Харківтурист», ПрАТ «Дніпро», ПрАТ «Готелі Трускавця" та ПрАТ «Тернопіль-Готель» (код за КВЕД 55.10) за 2012-2017 рр. Крім того, в табл. 1 представлена інформація про фінансовий леверидж розглянутих підприємств.

Випадки істотних різниць значень ROTA і ROTA $_{\text {EвIT }}$ (як, наприклад, в ПрАТ «ТернопільГотель») відповідають порівняно високим рівням фрінансового левериджу (ПрАТ «ТернопільГотель" має максимальні значення левериджу порівняно з усіма розглянутими підприємствами протягом досліджуваного періоду часу). Випадки малих відмінностей між ROTA i ROTA $A_{E B I T}$ (як, наприклад, в ПрАТ «Готель Дніпро») відповідають низькому левериджу. Природно, якщо аналітик ставить за мету під час оцінювання рентабельності активів абстрагуватися від структури капіталу, необхідності віддавати перевагу коефіцієнтам ROTA EвIT або ROTA $A_{E B I T D A}$. Графрічний розвідувальний аналіз сигналізує про суттєву відмінність значень ROTA EBITDA $_{\text {від ROTA }}$ і i ROTA $_{\text {EBIT }}$ у ПрAT

Таблиця 1

Динаміка рентабельності сукупних активів та левериджу ПрАТ “Харківтурист», ПрАТ «Дніпро», ПрАТ «Готелі Трускавця» та ПрАТ «Тернопіль-Готель» (код за КВЕД 55.10) за 2012-2017 рр.

\begin{tabular}{|c|c|c|c|c|c|c|}
\hline \multirow{2}{*}{ Підприємство } & \multicolumn{6}{|c|}{ Рік } \\
\hline & 2012 & 2013 & 2014 & 2015 & 2016 & 2017 \\
\hline \multicolumn{7}{|c|}{$\operatorname{ROTA}_{N P}$} \\
\hline ПрАТ «Харківтурист» & 0,00475 & 0,00024 & $-0,01169$ & 0,01387 & 0,00853 & 0,02014 \\
\hline ПрАТ «Готель Дніпро» & 0,00288 & $-0,00357$ & $-0,01040$ & 0,00153 & $-0,00257$ & 0,00047 \\
\hline ПрАТ «Готелі Трускавця» & $-0,07881$ & 0,09854 & $-0,10525$ & $-0,11448$ & $-0,14044$ & $-0,05478$ \\
\hline ПрАТ «Тернопіль-Готель» & 0,07388 & 0,00430 & $-0,05386$ & 0,01664 & 0,03342 & 0,05557 \\
\hline \multicolumn{7}{|c|}{$R O T A_{E B I T}$} \\
\hline ПрАТ «Харківтурист» & 0,01995 & 0,01280 & $-0,00102$ & 0,02277 & 0,01111 & 0,02464 \\
\hline ПрАТ «Готель Дніпро» & 0,00454 & $-0,00357$ & $-0,01040$ & 0,00153 & $-0,00165$ & 0,00063 \\
\hline ПрАТ «Готелі Трускавця» & $-0,04619$ & 0,13049 & $-0,10112$ & $-0,11117$ & $-0,14044$ & $-0,05478$ \\
\hline ПрАТ «Тернопіль-Готель» & 0,09574 & 0,04563 & 0,01336 & 0,07020 & 0,08156 & 0,08673 \\
\hline \multicolumn{7}{|c|}{$R^{\prime}{ }^{\prime}$} \\
\hline ПрАТ «Харківтурист» & 0,10663 & 0,07388 & 0,06479 & 0,09526 & 0,10594 & 0,18384 \\
\hline ПрАТ «Готель Дніпро» & 0,01660 & 0,00529 & $-0,00234$ & 0,00949 & 0,00809 & 0,01233 \\
\hline ПрАТ «Готелі Трускавця» & 0,00163 & 0,18134 & $-0,04747$ & $-0,05567$ & $-0,08247$ & 0,00403 \\
\hline ПрАТ «Тернопіль-Готель» & 0,12448 & 0,07841 & 0,04687 & 0,10410 & 0,11867 & 0,12373 \\
\hline \multicolumn{7}{|c|}{ Debt-to-Equity Ratio } \\
\hline ПрАТ «Харківтурист» & 0,11517 & 0,11420 & 0,12551 & 0,08689 & 0,10439 & 0,16655 \\
\hline ПрАТ «Готель Дніпро» & 0,02401 & 0,01825 & 0,01946 & 0,03563 & 0,03509 & 0,03532 \\
\hline ПрАТ «Готелі Трускавця» & 0,18128 & 0,01659 & 0,04829 & 0,1104 & 0,20646 & 0,35463 \\
\hline ПрАТ «Тернопіль-Готель» & 0,22589 & 0,39982 & 0,44689 & 0,42860 & 0,42128 & 0,42279 \\
\hline
\end{tabular}




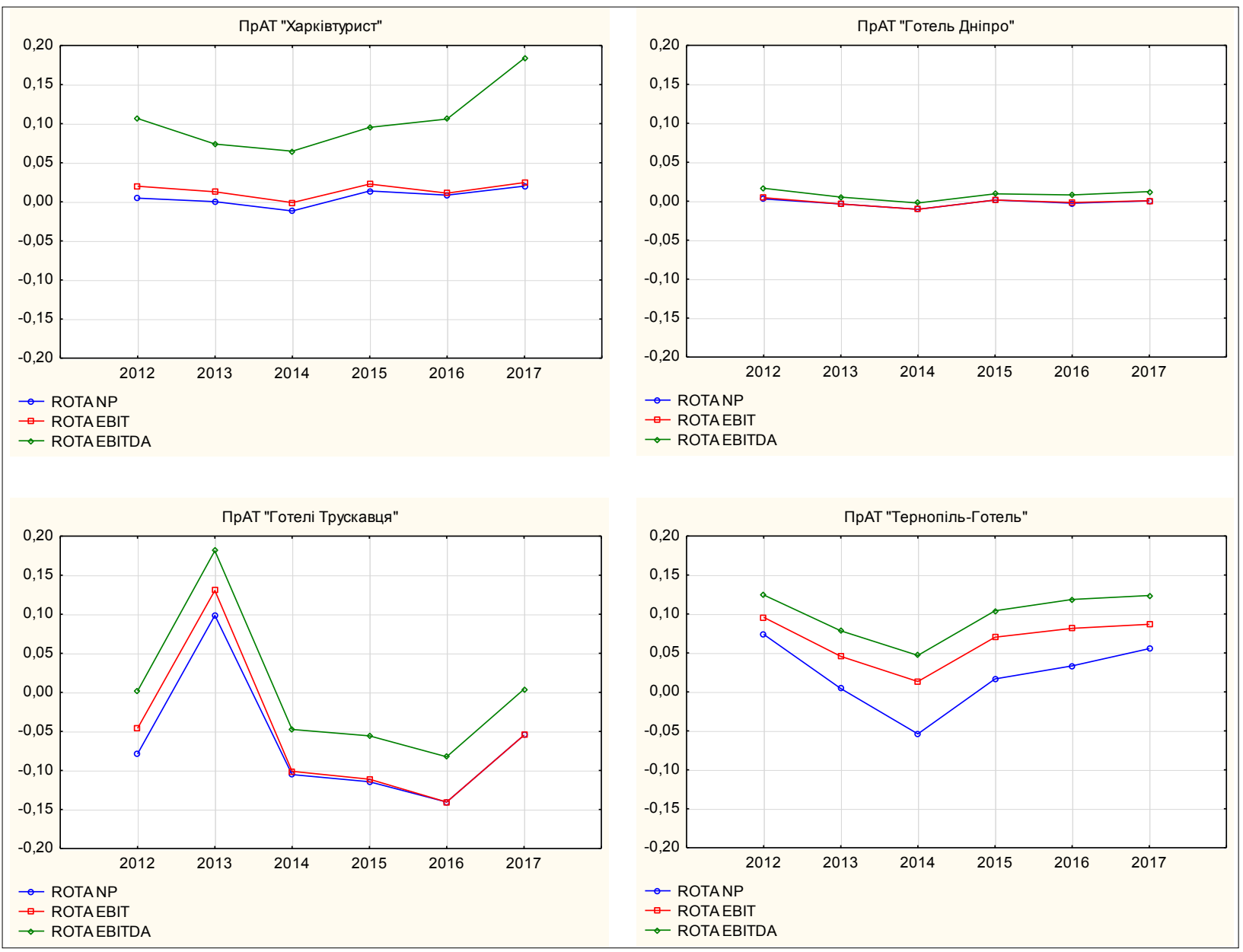

Рис. 1. Динаміка рентабельності сукупних активів ПрАТ «Харківтурист», ПрАТ «Дніпро», ПрАТ «Готелі Трускавця" та ПрАТ «Тернопіль-Готель» (код за КВЕД 55.10) за 2012-2017 рр.

"Харківтуріст», а також про меншу відмінність показників у ПрАТ «Готелі Трускавця» та ПрАТ «Тернопіль-Готель». Водночас відмінності значень розглянутих коефіцієнтів у ПрАТ «Готель Дніпро" присутні, але значно менш виражені. Як було сказано вище, порівняльний аналіз на

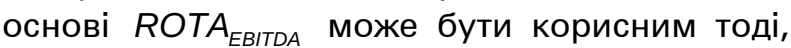
коли необхідно виключити вплив облікової політики та методів амортизації основних засобів і нематеріальних активів.

Більш детальний аналіз передбачає конструювання коефіцієнтів рентабельності за окремими групами активів, а вибір конкретної форми коефіцієнтів диктується цілями аналізу. Так, А.А. Нежад, О. Ямралі, М.Р. Абоуйафрарі (2014 р.) під час розрахунку рентабельності необоротних активів (Return on Fixed Assets, ROFA) в чисельнику зазначають валовий прибуток (Total Earning), а в знаменнику - чисту вартість необоротних активів, тобто вартість основних засобів за вирахуванням амортизації (Net Fixed Assets) [1]:

$$
\text { ROFA }=\frac{\text { Total Earning }}{\text { Net Fixed Assets }} .
$$

Розрахунок ROFA за фрінансовою звітністю НП(С)БО України може бути здійснений в такий спосіб:

$$
\text { ROFA }=\frac{\text { код рядка } 2090 \text { (або код рядка 2095) }}{\text { код рядка } 1010}
$$

М. Болек (2014 р.) основним показником, що допомагає оцінити оптимальний рівень оборотних активів, називає рентабельність поточних активів (Return on Current Assets, $R C A)$. При цьому пропонується не враховувати під час розгляду все фрінансові інвестиції, адже поточні активи слід зменшити на суму цінних паперів, що приносять дохід. Як зазначає М. Болек (2014р.), проблема управління рентабельністю поточних активів безпосередньо пов'язана з пошуком оптимального співвідношення прибутковості та ризику, рентабельності та ліквідності [3].

Загалом в кожному конкретному випадку система коефіцієнтів рентабельності активів може бути складена відповідно до цілей аналізу та впорядкована відповідно до різних класифрікаційних ознак. Зокрема, можливим є використання класифікацій, наведених І.В. Причепою (2012р.): 
1) за формами фрункціонування (матеріальні, нематеріальні, фрінансові, біологічні);

2) за характером участі в господарському процесі (оборотні та необоротні);

3) за характером участі в різних видах діяльності (операційні, інвестиційні);

4) за можливістю амортизації (ті, що амортизуються; ті, що не амортизуються);

5) за ступенем цінності (цінні, малоцінні);

6) за ступенем ліквідності (абсолютно ліквідні, високоліквідні, середньо ліквідні, мало ліквідні, неліквідні) [11].

При цьому в знаменнику фрормули рентабельності відповідного активу зазначається величина цього активу. Щодо чисельника коефріцієнта рентабельності активів, то це питання, як уже зазначалось, продовжує залишатися дискусійним.

Під час комплексного аналізування успішності діяльності фрірми неможливо ізолювати оцінювання рентабельності та оцінювання ліквідності. Вибір конкретного набору показників диктується цілями дослідження. Бажано уникати невмотивованого застосування функціонально взаємопов'язаних між собою індикаторів. Проілюструємо це твердження таким прикладом:

$$
\operatorname{ROTA}_{N P}=\frac{N P}{T A}=\frac{N P}{T A} \cdot \frac{S}{S}=\frac{N P}{S} \cdot \frac{S}{T A},
$$

де $S$ - виручка від продажів, або чистий дохід від реалізації продукції (товарів, робіт, послуг) (Sales Revenue), код рядка 2000 Звіту про фрінансові результати (Звіту про сукупний дохід); $\frac{N P}{S}$ - рентабельність продажів (Net Profit Margin, NPM); $\frac{S}{T A}$ - оборотність активів (Assets Turnover, $A T$ ).

Таким чином, маємо таку функціональну залежність:

$$
\operatorname{ROTA}_{N P}=N P M \cdot A T .
$$

Одночасне включення в систему показників результативності діяльності підприємства коефіцієнтів, що входять в праву й ліву частини фоормули (13), недоцільно. Якщо в такій системі показників вже має місце коефіцієнт рентабельності продажів (Net Profit Margin), доцільно доповнити її коефіцієнтом оборотності активів (Assets Turnover) замість коефіцієнта рентабельності активів (Return on Total Assets, ROTA).

Висновки 3 проведеного дослідження. Отже, як видно з проведеного дослідження, сучасна практика фрінансового аналізу оперує дуже великим набором коефіцієнтів рентабельності активів, причому далеко не завжди за назвою можна однозначно визначити методику розрахунку показника. Така обставина істотно ускладнює проведення порівняльних аналітичних розрахунків та вимагає підготовчої роботи, пов'язаної з узгодженням методики. Крім того, необхідно брати до уваги цілі аналізу та особливості аналітичного потенціалу того чи іншого показника. Так, наприклад, як було показано вище, розрахунки рентабельності сукупних активів за чистим прибутком, а саме $E B I T, E B I T D A$, дадуть різні результати щодо врахування структури капіталу, податкового навантаження, облікової політики та методу нарахування амортизації.

Наукова новизна полягає в уточненні аналітичних можливостей різних метрик рентабельності активів з урахуванням структури капіталу, фрінансового левериджу, облікової політики та методів амортизації основних засобів і нематеріальних активів; систематизації методик розрахунку коефіцієнтів рентабельності активів.

Результати дослідження можуть бути використані під час проведення порівняльних аналітичних досліджень підприємств різних форм власності, різної галузевої та національної приналежності.

Перспективи подальших розвідок у цьому напрямі можуть бути пов'язані з уточненням перспектив подальшого розвитку національних фрорм фрінансової звітності задля забезпечення найбільш релевантного подання інформації, необхідної для проведення порівняльного економічного аналізу ефективності використання активів підприємства.

\section{Список використаних джерел:}

1. Nezhad A.A., Yamrali O., Aboujafari M.R. The Impact of Intellectual Capital on Return of Fixed Assets and Firms Total Assets Return Which Listed On the Tehran Stock Exchange. Asian Economic and Financial Review. 2014. Vol. 4. № 10. P. 1409.

2. Dizkirici A.S., Topal B., Yaghi H. Analyzing the Relationship between Profitability and Traditional Ratios: Major Airline Companies Sample. Journal of Accounting, Finance and Auditing Studies. 2016. № 2 (2). P. 96-114.

3. Bolek M. Return on current assets, working capital and required rate of return on equity. e-Finanse: Financial Internet Quarterly. 2014. Vol. 10. №. 2. P. 1-10. DOI: 10.14636/1734-039X_10_2_005. URL: https://www.econstor.eu/bitstream/10419/147095/1/816178240.pdf (дата звернення: 21.03.2019).

4. Oberholzer $M$. The relative importance of financial ratios in the creation of shareholders' wealth. South African Journal of Economic and Management Sciences. 2012. № 15 (4). P. 416-428. 
5. Bos J., Koetter M. Handling losses in trans log profit models. Applied Economics. 2009. № 41. P. 1466-1483. URL: https://www.uu.nl/sites/default/files/rebo_use_dp_2007_07-17.pdf (дата звернення: 21.03.2019).

6. Озеран А.В. EBIT: Можливості наведення у фрінансовій звітності. Розвиток обліку, аналізу $i$ аудиту суб'єктів суспільного інтересу : матеріали міжнародної наукової конференції (Житомир, 20-21 жовтня 2017 р.). Житомир, 2017. С. 110-112.

7. Ларікова Т.В. Оцінка кредитоспроможності позичальників банків на основі моделей ймовірності банкрутства. Вісник Одеського національного університету. Серія: Економіка. 2014. Т. 19. Вип. 2 (6). C. 68-72. URL: http://nbuv.gov.ua/UJRN/Vonu_econ_2014_19_2(6)_17 (дата звернення 21.03.2019).

8. Андросова Т.В., Круглова О.А., Козуб В.О. Світовий та вітчизняний досвід визначення фінансового результату як об'єкта моніторингу на торговельному підприємстві. Проблеми економіки. 2014. № 3. C. 194-201.

9. Побережна Н.М. Фінансова звітність у системі управління підприємством. Східна Європа: економіка, бізнес та управління. 2017. Вип. 6 (11). С. 335-340. URL: http://www.easterneurope-ebm.in.ua/ journal/11_2017/65.pdf (дата звернення: 21.03.2019).

10. Єршова $\overline{\mathrm{H}}$.Ю. Методичний підхід до фоормування інформації в системі стратегічного управлінського обліку з метою підвищення економічної безпеки суб'єктів господарювання. Науковий вісник Міжнародного гуманітарного університету. Серія: Економіка і менеджмент. 2015. Вип. 10. С. 276-280.

11. Причепа І.В. Теоретичні засади управління активами підприємства. Економічний простір. 2012. № 60. С. 249-257.

12. Агентство з розвитку інфраструктури фондового ринку України. База даних фбінансової звітності емітентів. URL: https://smida.gov.ua/db/emitent (дата звернення: 21.03.2019).

13. Діяльність суб'єктів господарювання : статистичний збірник. Київ, 2018. URL: http://www.ukrstat.gov.ua/druk/publicat/kat_u/2018/zb/11/zd_2018.pdf (дата звернення: 21.03.2019).

14. Національне положення (стандарт) бухгалтерського обліку 1 «Загальні вимоги до фінансової звітності». База даних «Законодавство України». URL: https://zakon.rada.gov.ua/laws/show/ z0336-13 (дата звернення: 21.03.2019). 